\title{
Valuation as Evaluating and Valorizing
}

\author{
François Vatin
}

\begin{abstract}
The notion of valuation often blurs a distinction that is crucial to the understanding of economic processes: the distinction between processes of assessment (in which things undergo judgements of value) and processes of production (in which things are produced so as to be of value). Adapted from the introduction of an influential collection of essays edited by François Vatin and first published in French in 2009, this essay aims to clarify this problem. Based on a collective research venture by a group of social scientists in France, this essay revisits the sociology of evaluation using the sociology of work, and signals the analytic distinction between the two faces of valuation: evaluating and valorizing (in French, évaluer and valoriser). The text was translated from French by Juliette Rogers and revised by Alexandra Bidet.
\end{abstract}

Key words: evaluation; valorization; Marx; sociology of labour; metrology

The French language helps us to understand valuation as a creative process, by distinguishing evaluating (évaluer) and valorizing (valoriser). At first glance this may seem paradoxical, because, as John Dewey demonstrated so well (1939), the English language favours verbs over nouns, and valuation over value. However, I argue here that the French language helps us to stress, within valuation, the difference between "assessment of value" (évaluer) and "production of value" (valoriser), both confused in English by the most common words: "valuation", "valuing," or "valuating."

In this programmatic paper, I contend that valuation studies need to draw this distinction in order to build on the achievements of the sociology of work. At the core of John Dewey's valuation theory, the ordinary process of inquiry continuously bridges the cognitive and the affective, the intellectual and the emotional sides of valuation (Bidet, Quéré, and Truc 2011). While seeking what is valuable or desirable, or

François Vatin, Université Paris Ouest, IDHE, UMR CNRS 8533, France, vatin@uparis10.fr

(C) 2013 François Vatin

LiU Electronic Press, DOI 10.3384/vs.2001-5992.131131

http://valuationstudies.liu.se 
what worth is, we do not dismiss prices or limit interpretations to social values. Contrary to David Stark, I think that "how prizing and appraising translate to pricing" should not be left to corporate research departments or economists (Stark 2011), for two reasons. The first is because they are part of what valuation studies are about: studying everyday inquiries about what is desired, cared about, or held precious-inquiries through which, according to John Dewey, people go from immediate valuations to more reflexive ones (asking themselves "Is it really worth it?"). The second reason, as true for economic sociology as for the sociology of work, is that these inquiries are conducted on both sides of the production equation: by users and consumers, but also by workers, managers, and engineers. For the latter, performing valuations has to do with producing economic value, namely, valuable transformations in the world that will be worth the price for others (asking "Is it worth something?").

Hence, in the relatively neglected field of work and organizations (with the exception of Stark 2009), I argue here for an approach to valuation based on evaluation and valorization. This stance has multiple consequences, one of which is that prices are not-as one may think and as suggested in a way by David Stark (2011) —an (overly) simple metric of what is valuable, something that economic sociologists should avoid in favour of more valuable metrics. In fact, prices are indeed in play, as means and as consequences, in many inquiries on what is valuable.

\section{Valuation and Measurement: From Economic Theory to Economic Sociology}

Evaluer [to evaluate]: Transitive verb (fourteenth century, variation of avaluer, composed of value.

1) To determine (precisely or approximately) the value, the price of something. See estimer, priser, expertiser, calculer, chiffrer, supputer, coter... [to estimate, appreciate, appraise, calculate, number, work out, quote...].

2) By extension, to fix approximately. See apprécier, estimer, juger [appreciate, estimate, judge].

Valoriser [to valorize]: Transitive verb (early twentieth century, after valorisation; derived from valeur).

1) To produce an increase of market value, to increase the price.

2) To increase the value, the esteem given to something. (As with valable (valuable), this word is criticized in quantitative usages. It is in frequent and normal use in philosophy and psychology.)

If one is to believe these two definitions, taken from the Dictionnaire alphabétique et analogique de la langue française, a classic French dictionary by Paul Robert (1966), the primary meanings of "évaluer" (to evaluate) and "valoriser" (to valorize) are both of an economic nature. Évaluer is the older word, based on the old French 
avaluer, which passed through an intermediate form esvaluer in the $14^{\text {th }}$ century; its metaphorical meaning has come into common usage. ${ }^{1}$ On the other hand, Paul Robert tells us that purists criticize the parallel semantic extension of valoriser; its primary definition dates to 1925, and has a strictly economic meaning, "to increase market value," and its first figurative definition, "to give a greater importance to something," dates to $1943 .^{2}$ Évaluer's large semantic field is surely commensurate with the polysemy of the word "valeur" (value). This is also what allows us to predict, despite the purists, a growing extension of the usage of valoriser (to valorize, to give worth to). But whether we interpret these words in their strictly economic senses or whether we consider them in a wider semantic field, their comparison brings us to a classic opposition in economics: "to evaluate" (évaluer) corresponds with a static judgement attributing a value to a good, a thing, a person; on the other hand "to valorize" (valoriser) has a dynamic meaning-increasing a value, adding an increment to it, a surplus value. ${ }^{3}$

This detour through semantics thus brings us to classic economic theory, that of Karl Marx, in particular. Based on Aristotle's theory of exchange, Marx wondered if in fact a "surplus value" might emerge in an economic process composed of a group of exchanges, since each exchange establishes equivalence between two goods (Marx 2011). This equivalency manifests itself in the swap $\mathrm{M}^{-\mathrm{M}^{1}}$ (merchandise for merchandise), but also in simple monetary exchange $\left(\mathrm{M}-\mathrm{m}-\mathrm{M}^{1}\right)$, which corresponds to two symmetrical evaluations of the two goods, $M$ and $\mathrm{M}^{1}$, in a single monetary sum $(\mathrm{m})$. In other words, and using the terms that interest us here, evaluation doesn't create value; it only updates a value present in the good. Marx thought that escaping the paradigm of exchange, based as it is on the principle of equivalence, was essential in order to explain valorization, the creation of value. According to his famous phrase, it is only "in the secret laboratory of production" that one can hope to cast light on this mystery. This is why he devoted himself to a refined analysis of industrial organization, where labour emerges as the creative power at the origin of all value. For Marx, thinking of valorization is thinking of the creative act leading up to the

\footnotetext{
1 See Trésor de la langue française informatisé (http://atilf.atilf.fr/), which traces avaluer to 1283 and esvaluer to 1366.

2 Trésor de la langue française, op. cit., which refers to Le Corbusier for the first meaning and Gaston Bachelard for the second.

3 Economic theory borrowed this opposition between "static" and "dynamic" from physics. See Vatin (1998) for the exemplary case of Cournot, or Mirowski (1989) for a more general treatment of relations between economics and physics.
} 
mercantile sphere; on the market, only the values which are already there are fulfilled, and these values are the product of labour. ${ }^{4}$

Contemporary economic theory, however, seems to have rid itself of this problem. According to the theory of general equilibrium proposed by Léon Walras (1984), the notion of value (understood as economic) wouldn't have meaning outside of the mercantile sphere. Goods don't have intrinsic value; they acquire it on the market through the encounter of the ensemble of supplies and demands, each of which manifests the conditions of its technical acquisition by "producers" and those of its usage by "consumers." If one were to adopt such a schema, evaluation and valorization could no longer be dissociated. Value is created by the complex combination of the ensemble of evaluations (the confrontation of supplies and demands). The limitation of Walras's schema has been acknowledged by some of his greatest admirers, including Joseph Schumpeter: it is fundamentally static; ${ }^{5}$ the schema could be used to consider the equilibrium of values, but not the process of the accumulation of value. Léon Walras's undertaking is in this case antithetical to Marx's: where the latter maintained that the focal point should be shifted, turning away from the mercantile sphere in order to think about valuing, the other deliberately limits his investigation to the mercantile sphere alone. Put another way, for Léon Walras's "pure" political economy, the goods are already there, as are consumers' uses, for that matter. The conditions of their production concern technology, even applied political economics, but not pure political economy, which determines the rules of exchange. ${ }^{6}$ As much as Karl Marx subjected the question

\footnotetext{
4 My objective here is not to study how Marx intended to resolve this "mystery" as such. Let's quickly recall that he proceeds in two steps: first, in the wake of classical economists, he establishes a relationship of equivalence between monetary magnitude and quantities of labour (labour theory of value) which assumes that the labour is calibrated to a homogeneous metric; next, he identifies a particular good on the market, the "labour power," which has the ability to produce labour, that is to say, value. The work force will produce more value than it costs, thus releasing "surplus value" to be appropriated by the capitalist (the theory of exploitation).

5 The explicit goal of Schumpeter's theory of entrepreneurship (1911/1926) was indeed to complement static economics with a dynamic economics. He considered Walras's schema, which concludes with the theorem of the zero-profit entrepreneur in a situation of pure and perfect competition, to be the most successful expression of economic statics. It should be completed with a dynamic economics based, according to Schumpeter, on the supra-rational behaviour of the entrepreneurinnovator. If Schumpeter's theoretical construction is very different from Marx's, their initial problem-getting past the static inherent in the concept of economic equilibrium with a dynamic approach—is quite similar.

6 Remember that Léon Walras distinguishes three branches of political economy: pure political economics (abstract exchange theory), applied political economics, and social economics.
} 
of evaluation to that of valorization, which he considered the major problem to be solved, Léon Walras reduced the question of valorization to that of evaluation.

Why spend so much time here on such a seemingly pedantic issue? For the great majority of current economists, Karl Marx's theory is at best of only archaeological interest. As for Léon Walras, even if they recognize the foundational importance of his theory, it seems to have been overtaken by contemporary developments in the theory of the market. What I have to say doesn't bear on these theories themselves, but on their logical foundations-and from this perspective the question remains active. The question is just this: is a theory of the market enough in and of itself?

For the last twenty-odd years, what is known as the "economics of conventions" has been giving a negative response to this question. ${ }^{7}$ According to its authors, economic exchange is only possible to the extent to which there is a pre-existing understanding (a "convention") on the "quality" of the exchanged goods and on the cognitive instruments that allow that quality to be measured. As they have shown, Walrasian theory itself includes a preconditional hypothesis that such a convention exists, in admitting that there is already a nomenclature of goods in place before the exchange which allows its actors to "understand each other," in the linguistic sense of the term. Because all the other characteristics of goods are supposedly known in the same terms by the actors in the exchange, they can debate the price as the only variable up for discussion. The market doesn't hold itself up solely by the force of its mechanism, or by logical coherence, as one might say. It is plunged into a vast and shimmering universe of social values constantly under construction and discussion. Convention theory thus invites another mode of articulation between evaluation and valorization, in considering evaluate now in a wider sense, in contrast to the more strictly economic meaning of valorize. Conventionalist economists show that before being able to exchange economically (to valorize one's products on the market), there must be agreement on some common measures or evaluations. In short, you have to evaluate in order to valorize.

According to such a schema, the economic value can't be dissolved into the market alone. But the sequence remains linear, with the market as point of leakage: it's a matter of thinking of the social conditions that make the market possible. The "new economic sociology," as it has developed in France over the past 15 years, has focused itself primarily on the mercantile relationship. ${ }^{8}$ As with the economics of conventions, it's a matter of conceiving of the social

\footnotetext{
7 See the summary presented in André Orléan (1994).

8 See Philippe Steiner's summary (2012).
} 
conditions (cognitive, material, relational, etc.) that make the market possible. In this respect, we can cite the seminal article of MarieFrance Garcia-Parpet $(1986,2007)$ on the Sologne strawberry market, which shows that the achievement of a pure market, in the Walrasian sense (an anonymous encounter between a supply and a demand) supposes the establishment of a mercantile institution using particular technical mechanisms, namely here, the organization of an auctionclock market. Likewise, the inspired thinking of Mark Granovetter (1973, 1974) underlines the importance of social networks in the fulfilment of mercantile relations, aiming to show that the market could not sustain itself alone, but is "built into" an ensemble of social relations that make it possible. Other authors, inspired by the sociology of science and technique, have shown the role of the sociotechnical arrangements and devices (packaging, the material structure of stores, etc.) that equip market actors and thus render the exchange possible (Barrey et al. 2000; Cochoy 2002). Economic science itself contributes to the performation of such types of calculation, as Michel Callon (1998) has demonstrated; the so-called homo oeconomicus is not at the foundation of economic relations, but rather a product of mercantile institutions.

From the economics of conventions to the sociology of markets, this line of thought has sought to open the "black box" of the market of neoclassical theory. In various forms, this body of research has addressed the issue of valuation and measurement. We saw it in the economics of conventions, which has the construction of places of shared judgement as its core issue. Likewise, authors who have worked on the equipping of markets have insisted on the importance of nonmonetary measuring mechanisms, such as industrial norms, mercantile certifications (such as organic and other labels; see Cochoy, 2000), classifications made by prescribers or market intermediaries (Michelin restaurant guides, store-generated informational schemes), ${ }^{9}$ and so on. Consumers, they have shown, bathe in a teeming metrological universe. Price may well be the ultimate market operator, but the mercantile relationship can't alone be reduced to the question of price formation, as standard economic theory would have it.

The metrology of the market described by both economics of conventions and sociology of markets increasingly affirms itself, as we leave the traditional universe of commerce based on interpersonal confidence (which links "suppliers" and "demanders" according to a logic of mutual knowledge of the concerned individuals) to enter into

9 See Karpik (2000), and more generally Karpik (2010). For the notion of "prescriptors," see also the classic article by Armand Hatchuel (1995). 
that of the industrially normed market. ${ }^{10}$ Trust, which is indispensable to the fulfilment of the mercantile exchange, is then based on the certification of the quality of goods by actors private (businesses, business groups) or public (state and international agreements)..$^{11}$ Less and less frequently, then, do products present themselves "naked" to the gaze of a client armed solely with his own intuitive capacity for judgement. They are first of all framed by the multiple metrologizations which are represented by what is written on the packaging and information on the modes and precautions for use, but they can also be traced back through the tentacular universe of organizations for normalization, certification, and evaluation; in laws, decrees, circulars, and international commercial agreements; and lastly in the archives of the tribunals which have to settle contentious disagreements (Stanziani 2005).

We approached the question via the market of goods, because it is the approach that is at the conceptual heart of "standard" economic theory, inspired by the neoclassical schema. According to this theory, labour is considered to be a good like any other, its price fixed on the market in relation to its "utility" for the buyer, or in other words, its productivity. This conceptual framework, indispensable to the completion of the Walrasian theory of general equilibrium, obviously constitutes a theoretical fiction requiring numerous arrangements to somewhat convincingly account for the observable facts. As Karl Polanyi pointed out, labour can't fully be merchandise, because it "is only another name for a human activity which goes with life itself" $(1944,72)$. As a result, it has always been the object of aggressive public control in order to guarantee the public order and social peace. Moreover, the exchange of labour is by its nature an interpersonal relationship, since labour is not dissociable from the person who "bears" it.

The very particular character of the merchandise "labour" explains how the study of its exchange (what's known, through the misuse of language, as "the job market") was at the origin of numerous critical analyses of the "standard" economic representation of the market. Thus Mark Granovetter $(1973,1974)$ highlighted the importance of social networks in market relationships to describe the pairing between employers and employees. Likewise the notion of the "qualification" of goods, as developed by the economics of conventions, transposes a

10 There we see the opposition between the "domestic world" and the "industrial world," as developed by Luc Boltanski and Laurent Thévenot (2006). There is also the seminal article of Pierre Boisard and Marie-Thérèse Letablier (1987).

11 Although many consider that the political is declining in favour of the mercantile, states and supra-national organizations have the dual possibilities of legal recourse when confronted with private engagements and establishing their own norms, which is significant—and continually growing—for everything relating to people's safety. 
concept developed for studying labour markets into the ensemble of markets, and in a context less concerned with the theory than with the practice of labour management. It seems obvious indeed that the valuation of workers is not exclusively an affair of the market-the professional hierarchy trains itself, well before the market, especially in educational institutions. Put another way, workers arrive on the market already marked by social certifications, and their "qualifications" are forged and valued in other metrological spaces. In a prolongation of network theory, conventionalist economists have also insisted on the importance of intermediation of the "job market," where the pairing isn't always achieved spontaneously, nor solely thanks to the informal networks highlighted by Mark Granovetter, but also through the bias of public or private institutions responsible for the valuation of work qualities to transform the demand for employment, especially that of the unemployed, into normalized qualities destined for employers (Eymard-Duvernay and Marchal 1997).

In many respects, the works gathered in Vatin (2009) took their inspiration from the research cited above, and illustrate them with new examples. ${ }^{12}$ This book has studies from the socio-economics of work bearing on modes of job qualification and regulation: the measurement of employability (Rémillon and Vernet 2009), the regulation of intermittent worker status in performance art professions (Grégoire 2009), and the transformation of the unemployed person into entrepreneur (Giraudeau 2009). Other contributions delve more into the organization of work itself: in telephony (Bidet 2009), at the hospital (Belorgey 2009), in the petrochemical industry and the national association for adult professional education (the AFPA) (Le Bianic and Rot 2009), and in the daily press (Cabrolié 2009). A third group of contributions is affiliated with research on the qualification of products: the normalization of the pressure cooker (Leymonerie 2009), the "red label" certification of Quercy farmhouse lamb (Escala 2009), the normalized definition of medications (Nouguez 2009), and the genesis of a new norm of "social quality" (Barraud de Lagerie 2009).

On diverse objects and with equally diverse approaches, this set of studies has kinship with already well-documented research that supports its findings. Approaching our objects through the issue of measurement allows us to place the problem of market equipment at the heart of our interrogations, namely, the study of the ensemble of prerequisite mechanisms which make exchange possible: goods and workers arrive on the market already calibrated, classified, and measured in many ways. The market price doesn't freely invent itself on the market as "standard" economic theory would have us believe; the price doesn't result from a disembodied negotiation in the

12 We are also grateful to Michel Callon, who kindly agreed to write an afterword. 
marketplace, because the objects being exchanged are already indexed by all these prior metrological operations that the market sanctions with a greater or lesser flexibility. As Lucien Karpik (2010) convincingly argued, price is thus not necessarily the exclusive variable for adjustment, the keystone of the entire economic structure, as postulated by standard economic theory.

On this point, Etienne Nouguez's paper on the market for generic drugs should be cited (Nouguez 2009). He shows us that a medication is a strange good, to say the least: it is the object of price differentiation, yet it is certified as equal by public health authorities. How to conceive of such a "monster" in standard economics, this twoheaded object made of two goods certified as "equivalent" which are only distinguished by price? Etienne Nouguez shows us what is at stake in this confrontation between two registers of equivalence: the "objective" equivalence granted by a tutelary authority (scientificlegal) and the "subjective" equivalence, left to consumers "free" of economic theory. The tension between these two registers of equivalence causes the growth of the economic surplus value, which then distributes itself among various market actors. In any case, the monetary price here is not the market adjustment variable, as assumed by economic theory; the price is even heavily controlled. And yet one can analyse strong tensions between actors on the distribution of value.

\section{Measurement in Action: The Work of Valorization}

After this review of the rich line of research that has fruitfully criticized the standard representation of mercantile relations and elaborated other instruments to apprehend them, I would now like to turn to what is needed to take the next step in analysis. I believe we need to move the focal point of study. The economics of conventions, as well as the new sociology of economics, are mainly focused on the study of mercantile relations, which practitioners sought to prove couldn't be reduced to the standard model of economic theory. Of course this work doesn't ignore questions of productive organization and firm management, but study of these aspects remains subordinate to that of the comprehension of the market mechanism itself. This choice may be understood first of all by the organization of scientific work: France has a rich tradition of sociological research on organizations and work, along with work by managers on productive organization. Moreover, in these cases, there was an entirely justifiable research strategy: tackling the study of mercantile relations, going straight to the heart of economic theory itself to identify its inadequacies, targeted right where it seemed to have the final response. But the risk then, in ignoring Marx's critique, was of adopting the 
perspective of the economists themselves by focusing all economic relations on a single point of leakage, the market.

Our undertaking reconnects in a way with Marx's interrogations on the necessary link that should be established between a theory of production and work, and a theory of the market and value. It is not, however, to return to a dogmatic construction of labour value, according to the solution Marx thought he'd found to the problem. That would close the question before even having raised it, by maintaining the existence of a universal metrology that could only have philosophical foundations. ${ }^{13}$ Opposite to this perspective, we situate ourselves in the spirit of an empirical sociology which seeks to identify the metrological spaces elaborated by actors, the meaning they give to them, and the effect of these measuring devices and equipment on social relations. In moving the production chain to this side of the mercantile realm, we seek to understand, in practical terms, the process by which valorization is ingrained in acts of work, by combining economic sociology and the sociology of work in a spirit of cross-pollination between the two research traditions.

One key concept that runs through the collected volume (Vatin 2009 ) is the agreed-on status given to the notion of work in economic sociology. ${ }^{14}$ The usual sequential schema is based on an opposition between the spaces of work and market, which reinforces the opposition between the technical instance and the economic one. Such a schema has the advantage of being compatible with the Walrasian representation of the market, according to which one may indeed isolate a productive space that results in products, determined by its own assemblage of norms (predominantly technical but also social, in the sense of social engineering-labour management techniques, for example). Subsequently, the question of the valorization of these products on the mercantile scene is raised, that of the establishment of the market price. The economist's work concerns only this second phase, the first belonging to technicians, managers, or even sociologists of work and organizations. 15

\footnotetext{
13 The issue here is not to critique the Marxist conception of labour value, which is in line with a theoretical economics that must be resituated in the internal and external contexts of elaboration of Marx's theory. I wish only to underline that here I borrow Marx's question, and not his response.

14 The notion of work here should be understood as a "productive action" (work activity) and not as an object subjected to the market (work merchandise). From Mark Granovetter's sociology of networks to François Eymard-Duvernay's economics of conventions, studies are indeed numerous on the economic sociology of "job markets."

15 This sharing of role between economists and managers has been well analysed and critiqued by Philippe Lorino (1989).
} 
I have shown why such a disconnection from reality is unsatisfactory (Vatin 2008a, 2008b). A clear dividing line cannot be established between the economist and the technologist, because technical thinking itself is fundamentally economic. The technical norm in fact relies on the efficiency principle, which is essentially economic, since it consists of setting a ratio between something considered to be a result or product and something thought of as an expense or cost. It's even the very definition of such a ratio relating products to costs, which is economic, and not the nature of the measurement units used to quantify the denominator and numerator. There is no division, only continuity between the more "technical" ratios, such as that of returns, and the more "economic," such as that of profitability, via the very ambiguous category of productivity. What this means, but which will not be demonstrated here, is that the technical ratios like mechanical return cannot be understood in a pure physical positivity. They can't be constructed without undertaking a division of the world incorporating norms of valuation into that which "costs" and that which "gains."

This perspective demands the redefinition of even the notion of economics, to free the universes of the market and monetary measurement from the limited space usually allotted to them in order to allow consideration of the many economic aspects of social actions, especially in the productive sphere. To this end, I proposed redefining economics as an act of management, that is, as a practice that, in an explicit or implicit calculation, takes consideration of the relationship between a product and an expenditure. Of course, it's in the work of technicians and managers, explicitly charged with elaborating norms, that one will first see such a conception of the economic at work. Many examples are found in the chapters of our book (Vatin 2009): engineer-normalizers designing the safety of pressure cookers; a telephony engineer developing a new economic good, "telephone communication"; hospital managers making economic measures of medical acts; editorial secretaries of daily newspapers inscribing journalists' work into normalized layouts; public health managers building the norm of generic medications; petrochemical managers and the AFPA normalizing the information processed by their companies' agents in order to depersonalize it; consultants elaborating evaluation criteria of social quality; food industry engineers developing evaluation criteria for lamb carcasses, and so on.

In so doing, we rejoin work carried out on the work of organizers and on the rationalization of management practices (Moisdon 1997). We focus on the metrological instruments put into use: lists, grills, measurements, ratios, calculatory devices. We concentrate particularly on the terms of their emergence, with the idea that in tracing them back to the conditions of their construction we can bring to light the valuation systems hidden in their "black box," once it has been 
institutionalized and operates as a "machine," according to the apt expression that Pauline Barraud de Lagerie takes up from Alain Desrosières (1998). Our attention to the genesis of norms distinguishes us from certain works critical of managerial domination that approach the question mainly through the ways these procedures are put in place, always considered destructive to social connections and to attentiveness to people and things-in short, like abstract mechanical processes devoid of all humanity (Maugeri 2001). It's not a matter of saying the management devices don't act sometimes as dehumanized machines, but to show that, in fact, like ordinary machines, they are indeed social productions full of valuations. Although doubtlessly their effects can never be reduced to their intentions, they still can't be reduced to blind natural forces, as they are sometimes represented.

Moreover, as far as activity is concerned, normative power is not the exclusive prerogative of organizers and managers. Here two steps should be distinguished: first, that of the genesis of instituted norms, then, that of the conditions of application of these norms. The genesis of norms requires technicity (that of an engineer, a lawyer, a manager, an accountant, etc.) and expresses social power, according to the two faces (knowledge and power) of all professionalisms. These norms incorporate the social order in the context of a hierarchized society where power rests largely on monetary might, a quick and convenient way to define what we commonly understand as "capitalism." It would, however, be an error to think that technical, administrative, or managerial norms are decreed without any form of social debate or concern about the general interest and extra-economic values.

Let's take a look at some of the studies collected: engineers working on the normalization of the pressure cooker had the ambition of developing its market to the advantage of its manufacturers, but also of providing the population with an economical and reliable instrument (Leymonerie 2009). Hospital managers are certainly charged with reducing costs in favour of the national healthcare system, but in doing so they represent a conception (sometimes debatable) of the general interest that does not ignore public health questions (Belorgey 2009). Managers at the French unemployment insurance organization (UNEDIC) try to reduce the cost of social benefits for performance arts professionals, but in a context of public funds that aim for a "fair" distribution of resources coming from social programme contributions (Grégoire 2009). Editorial staff of daily newspapers develop the paper's layout, or even its editorial line, in relation to the constraints of the advertising market, but they are not devoid of a journalistic ethic aiming to inform readers well (Cabrolié 2009). Consultants who elaborate "social quality" norms work first in the service of large businesses that want to fortify themselves against the risk of scandals linked to the denunciation of disastrous work conditions at their manufacturers in developing 
countries, but they also have ethical aspirations to improve working conditions worldwide (Barraud de Lagerie 2009).

Another principal developed in the texts is that normative power isn't unilateral, going from high to the low, from conception to execution. Such an idea isn't in and of itself original. It has been developed by many contributions to the sociology of organizations which have shown the valuing and normativizing power of "executants" by highlighting forms of "autonomous" or "conjoint" regulation, in Jean-Daniel Reynaud's terminology (1993). We develop a somewhat similar idea by underlining the managerial dimension of all work. The analysis first applies to "professionals" (doctors, hospital employees, petrochemical researchers, psychologists, etc.), who often "resist" the imposition of management instruments coming "from on high," but who also, through action, build their own axiological frames which are, in fact, management norms: what information to circulate between researchers or between psychologists, which ailments to care for in priority, and so on. These professionals have their own ethical frame, if not professional bodies, which are the foundation of their power to resist norms imposed from above. But such a normative capacity isn't absent among the personnel of execution: local auditors who fill out social quality evaluation forms and must interpret them, and "qualiticians" of the Quercy lamb slaughter chain, seeing over a hundred carcasses per hour, are charged with classifying them in a quality evaluation grid, thus producing, in an assembly line, a classification that will determine the price paid to the farmers (Escala 2009). No work, not even that of white-collar workers and professionals, escapes imposed normative measures; none is reduced to a pure and simple application of these measures without the necessity of making translations which engage, to varying degrees, the worker's own normativity.

This brings us back to the question of valuation. These works have the common objective of trying to grasp the process of value creation, both on the market and upstream from it, via the practical operations by which goods and services are measured, valued, and technically and economically elaborated, not just by the productive organizations that decree management norms, but also by the agents in charge of putting them into action, who can only do so in working around them, in reformulating them, and in combining them with their own valuations. The economic space, then, deploys itself in a singular way. Economic value here is no longer dissociable from other registers of valuation. The issue is to grasp how multiple valuation processes effectively lead to the circulation of economic value in the strictest sense, that is, to the genesis of monetary fluxes. Let's take some examples.

What is a telephonic communication? A verbal exchange over distance between two people, the significant product of this exchange, a quantity of energy which circulates for a given time over the 
network, an operator's work of putting in contact, a network's quantum of global availability? Asking such questions is to wonder about the material construction of the network and how its use is organized, as well as to consider its economic nature: what "costs" in a telephonic communication? What does a phone call bring in? What correspondence between the costs and the products might one establish so that a telephonic economy would be possible? As Alexandra Bidet shows, telecommunications engineers haven't stopped asking such questions (Bidet 2009). Their answers can't be interpreted as the progressive discovery of a hidden reality, according to a Platonic conception of the market. They are in the continuous production of their object itself, which is simultaneously a good of usage (which has changed with time), a technical device (which has known several revolutions), and an economic good susceptible to receiving a price, the very nature of which has not ceased to vary, either (billing by distance, by time, etc.).

Let's leave the obscure terrain of telephony for the sensible reality of lamb. Here we easily grasp the actors, well identified in their successive technical functions: farmers, a slaughterhouse, distributors (butchers and supermarkets), and lastly, the consumer. This linear technical chain can a priori be easily put in correlation to the economic chain (monetary flux) which follows it step by step, tracing a succession of exchanges that track the value back from consumer to farmer, following the reversed trajectory of the product's course. Thierry Escala's analysis of the case of red-label lamb singularly complicates the question (Escala 2009). It shows that the process of economic valorization is concentrated in two work stations on the slaughtering chain: that of the "qualitician," who classes carcasses according to a grid of conventions, and that of the "salesperson," who splits them up physically into lots destined for the slaughterhouse's customers (butchers and supermarket chains). At these two moments, values are "redistributed," like in a card game, toward the upstream in the case of the qualitician's station, and toward the downstream for the salesperson's. The market isn't as simple and linear as economic theory would have it. It's double-faced: there is no homogeneity between upstream value fluxes (towards farmers) and downstream value fluxes (towards consumers). Accounting equilibrium is maintained by a complex system of equalization. What is interesting here is that this complex economy of labelled lamb can't be revealed and understood without the concrete observation of the work practices of the qualitician and salesperson, which are intrinsically "technical" and "economic" at the same time.

A similar demonstration can be made based on the case of the manufacture of the daily newspaper (Cabrolié 2009). Here too, is a complex economic organization, since the newspaper's economic stability relies on two dissociated markets: that of the readership and 
that of the advertisers. But as Stéphane Cabrolié shows us, these two markets are closely connected in the paper's practical construction, since the economic stability (the balance between incomes from paper sales and advertising) ultimately manifests itself in a technical balance in the newspaper's material composition between editorial pages and promotional inserts. As with slaughterhouses, the complex economy of the newspaper can only be understood by correctly studying the division of work among journalists, editorial secretaries, editor-inchief, and printing service. The economy is not, as it's often represented, a tutelary - or malevolent-power which weighs on the work of professionals and employees, who in turn possess a rationality of an entirely other order: the journalist's ethics, the aesthetics of layout, etc. It is instead an organic component of work, made of arrangements and compromise between diverse normative registers, hierarchically imposed or indigenously constructed. As with slaughterhouses, only by focusing on the material management tools (the carcass qualification grid, the outline of the newspaper's composition) can we bring to light the complex system of valorization that is distributed in the ensemble of productive acts.

In light of these examples, evaluation no longer appears as a simple preliminary to valorization, as the economics of conventions would have it. All along the chain of production, valorization is present in acts of evaluation, in that they are provisional modalities for establishing a value that is under construction. As Thierry Escala says so well, we must get past the problematic of the static analysis of product qualification, as developed by the economics of conventions, in order to consider the work of qualification in a dynamic way. More generally speaking, acts of production can't be understood without thinking about how they insert themselves into the economic realm: the work of journalists and editorial secretaries incorporates the distinctive economic frame of their sector; emergency room doctors also integrate, in their own way and in an albeit conflictual way, hospital management staff; and pressure cooker engineer-designers, like those in telephony, think about the market for the goods they are also developing. Management is not only reserved for official managers, it permeates the entirety of productive activity. Economic conditions in the strict sense of the term (the space in which prices are formed) condition productive activity, not only in the mode of hierarchical constraint and imposed norms, elaborated by managers based on economic analysis of the organization and of its integration in the market or public accounts, but also through the normativity that is indigenous to workers, who, in their own way, also think about economic constraints. Inversely, when goods arrive on the market they are already equipped with all the pre-market valuations that had been incorporated into management devices (those explicitly imposed by the 
hierarchy), as well as some informal valuations resulting from the economic reflexivity of the workers at any level of the firm.

We need to open a new chapter of thought at the crossroads of sociology, economics, and management: to think about value and valuation in the activity of work itself, in the double register of the genesis of norms taking place simultaneously with the practice of professional activity, from top to bottom of the professional hierarchy, and the ever-relative effectiveness of the imposed norm. Moreover, these two registers are not unrelated, because it's often in reaction to the imposed norm that the actors' own normativity expands. We find diverse examples in the texts cited above, from very diverse professions: hospital doctors, AFPA psychologists, petrochemical researchers, and even performing artists through their activist organizations. After all is said and done, actual practices come under what we might call "joint normativity," in the way that Jean-Daniel Reynaud (1989) spoke of “joint regulation.” As Jean Saglio (2007) has highlighted, such practical agreements don't remotely require that participants agree on the foundational questions, on the ideological level. To the contrary, it's often because each may interpret the norm according to his or her own valuations that practical agreements are possible. This stance is especially reminiscent of Dewey's “practical agreement" (1939); it also pertains to the well-known concept of "boundary objects" (Star and Griesemer 1989). Mathieu Grégoire gives a powerful illustration of this configuration concerning the formula for calculating the unemployment compensation for performance art professionals (Grégoire 2009). He shows that the two parties actually did come to an agreement following a long conflict over a new compensation formula, but with each attributing radically different meanings to the formula, and what's more, without ever actually arriving at an explicit agreement.

The studies we collected in Vatin (2009) illustrate the construction of norms through action, showing how a universe of practical norms is created to deal with the technical naturalness of the treated objects: the expansion of steam in the pressure cooker, the waves that circulate in wires, and the social framework in which these objects in practice get their meanings and can consequentially be the object of work and of an economy. We also deal with the supervision of work through measurement devices. How to measure, to control, to guide, to finance? The "how" here doesn't refer back to the authors' normativity, but to the close examination of a measurement, an accounting formula, a management instrument, a model for business creation, and so on. We analyse work by the norm imposed on it, even if we show both the workers' resistance to this norm and their own normative capacities. Ultimately, exploring work as an activity producing measurements is to explore its producing value and valuations. 


\section{Conclusion}

To provisionally conclude this essay, I suggest that valuation has two faces. It is a vital process that comes with and within any productive undertaking, in the most general sense that one can give to the expression; it is thereby also a system of social regulation to be dealt with. This echoes a classic pattern in neoclassical economic theory, which considers market actors as both "price makers" and "price takers." This theory grants the "market," as an abstract and universal calculative instance, a magical power to solve this contradiction. To this end, Léon Walras imagined the figure of the "auctioneer," a sort of "Maxwell's demon" of the market, who embodies the calculative device. I approach things differently. In a more descriptive and pragmatist-inspired stance, I contend that we should identify the confrontation of various norms, which instead of being stacked are temporally articulated with reversionary effects.

At this point, this new approach is still in the early stages of its drafting: a general grammar of valuations has to be developed. But it has the merit of highlighting the dynamics of valuation that, as we have seen above, escapes the neoclassical economic theory focused on the scheme of equilibrium. This theory assumes that the market, by assigning a value to each good, statically balances the account of each agent. This assumption makes the very conception of economic dynamics impossible. On the opposite side, the effort to account for the actor in the dynamics of his own economic actions (that is, in his ability to produce value) reopens the "black box" of value creation, which economists have left to managers and to which economic sociologists have, until now, paid little attention. The French language, which distinguishes between evaluation and valorization, helps to present the problem more clearly. This distinction reaffirms the importance of the notion of work as a productive activity in the wake of classical economic thinking, Marx's in particular. In this sense, the theory of valuation is at the heart of an approach to economic sociology that, instead of being centred on the figure of the market, is primarily a concrete sociology of productive activity. As such, it is a highly promising research agenda.

\section{References}

Barraud de Lagerie, Pauline. 2009. "Objectiver la qualité sociale.” In Evaluer et valoriser: Une sociologie économique de la mesure, edited by François Vatin, 229-45. Toulouse: Presses universitaires du Mirail.

Barrey, Sandrine, Franck Cochoy, and Sophie Dubuisson-Quellier. 2000. "Designer, Packager, Merchandiser: Trois professionnels pour une même scène marchande." Sociologie du travail 42 (3): 457-82. 
Belorgey, Nicolas. 2009. "Offrir les soins à l'hôpital avec mesure.” In Evaluer et valoriser: Une sociologie économique de la mesure, edited by François Vatin, 73-89. Toulouse: Presses universitaires du Mirail.

Bidet, Alexandra. 2009. "Valoriser la communication: L'appel utile." In Evaluer et valoriser: Une sociologie économique de la mesure, edited by François Vatin, 55-71. Toulouse: Presses universitaires du Mirail.

Bidet, Alexandra, Louis Quéré, and Gérôme Truc. 2011. "Ce à quoi nous tenons: Dewey et la formation des valeurs.” Introduction to La formation des valeurs, by John Dewey, 5-64. Paris, La Découverte.

Boisard, Pierre, and Marie-Thérèse Letablier. 1987. "Le camembert: Normand ou normé. Deux modèles de production dans l'industrie fromagère." In Entreprises et produits, Cahiers du Centre d'études de l'emploi 30:1-30.

Boltanski, Luc, and Laurent Thévenot. 2006. On Justification: Economies of Worth. Princeton: Princeton University Press.

Cabrolie, Stéphane. 2009. "La double vente du journal quotidien." In Evaluer et valoriser: Une sociologie économique de la mesure, edited by François Vatin, 177-95. Toulouse: Presses universitaires du Mirail.

Callon, Michel, ed. 1998. The Laws of the Markets. Oxford: Blackwell.

Cochoy, Franck. 2000. "De l'Afnor à la NF, ou la progressive marchandisation de la norme industrielle." Réseaux 200:63-89.

- 2002. Une sociologie du packaging, ou l'âne de Buridan face au marché. Paris: Puf.

Desrosières, Alain 1998. The Politics of Large Numbers: A History of Statistical Reasoning. Cambridge: Harvard University Press.

Dewey, John. 1939. “Theory of Valuation.” In Vol. II, no. 4 of International Encyclopedia of Unified Science, edited by Otto Neurath, Rudolf Carnap, and Charles W. Morris. Chicago: University of Chicago Press.

Escala, Thierry. 2009. "Les valeurs de la carcasse." In Evaluer et valoriser: Une sociologie économique de la mesure, edited by François Vatin, 197210. Toulouse: Presses universitaires du Mirail.

Eymard-Duvernay, François, and Emmanuelle Marchal. 1997. Façons de recruter. Paris: Métailié.

Garcia-Parpet, Marie-France. 1986. "La construction sociale d'un marché parfait: Le marché au cadran de Fontaines-en-Sologne." Actes de la recherche en sciences sociales 65:2-13.

- 2007. "The Social Construction of a Perfect Market: The Strawberry Auction at Fontaines-en-Sologne." In Do Economists Make Markets? On the Performativity of Economics, edited by Donald MacKenzie, Fabian Muniesa and Lucia Siu, 20-53. Princeton: Princeton University Press.

Giraudeau, Martin. 2009. "Formuler les projets d'entreprise." In Evaluer et valoriser: Une sociologie économique de la mesure, edited by François Vatin, 137-54. Toulouse: Presses universitaires du Mirail.

Granovetter, Mark. 1973. "The Strength of Weak Ties.” American Journal of Sociology 78 (6): 1360-80. 
1974. Getting a Job: A Study of Contacts and Careers. Chicago: University of Chicago Press.

Grégoire, Mathieu. 2009. "Attribuer une valeur au hors-emploi: L'intermittence du spectacle." In Evaluer et valoriser: Une sociologie économique de la mesure, edited by François Vatin, 93-113. Toulouse: Presses universitaires du Mirail.

Hatchuel, Armand. 1995. "Les marchés à prescripteurs: Crise de l'échange et genèse sociale.” In L'inscription sociale du marché, edited by Annie Jacob and Hélène Vérin, 205-25. Paris: L'Harmattan.

Karpik, Lucien. 2000. "Le guide rouge Michelin." Sociologie du travail 42 (3): 369-89.

- 2010. Valuing the Unique: The Economics of Singularities. Princeton: Princeton University Press.

Le Bianic, Thomas, and Gwenaële Rot. 2009. "Cadrer les cadres." In Evaluer et valoriser: Une sociologie économique de la mesure, edited by François Vatin, 155-74. Toulouse: Presses universitaires du Mirail.

Leymonerie, Claire. 2009. "Dompter la cocotte-minute." In Evaluer et valoriser: Une sociologie économique de la mesure, edited by François Vatin, 35-53. Toulouse: Presses universitaires du Mirail.

Lorino, Philippe. 1989. L'économiste et le manager. Paris: La Découverte.

Marx, Karl. 2011. Capital, Vol. 2: A Critique of Political Economy. Mineola: Dover.

Maugeri, Salvatore. 2001. Délits de gestion. Paris: La Dispute.

Mirowski, Philip. 1989. More Heat than Light: Economics as Social Physics, Physics as Nature's Economics. Cambridge: Cambridge University Press.

Moisdon, Jean-Claude, ed. 1997. Du mode d'existence des outils de gestion: Les instruments de gestion à l'épreuve de l'organisation. Paris: Seli Arslan.

Nouguez, Etienne. 2009. "Construire l'équivalence: Le médicament générique." In Evaluer et valoriser: Une sociologie économique de la mesure, edited by François Vatin, 211-27. Toulouse: Presses universitaires du Mirail.

Orléan, André, ed. 1994. Analyse économique des conventions. Paris: Puf.

Polanyi, Karl. 1944. The Great Transformation: The Political and Economic Origins of Our Time. New York: Farrar and Rinehart.

Rémillon, Delphine, and Antoine Vernet. 2009. "De l'inaptitude à l'inemployabilité." In Evaluer et valoriser: Une sociologie économique de la mesure, edited by François Vatin, 115-35. Toulouse: Presses universitaires du Mirail.

Reynaud, Jean-Daniel. 1989. Les règles du jeu. Paris: Armand Colin.

Robert, Paul. 1966. Dictionnaire alphabétique et analogique de la langue française. Paris: Le Robert.

Saglio, Jean. 2007. "L'ordre salarial en France: La faiblesse du consensus, gage de stabilité." In Le salariat: Théorie, histoire, formes, edited by François Vatin, 187-206. Paris: La Dispute. 
Schumpeter, Joseph A. 1911/1926. The Theory of Economic Development: An Inquiry into Profits, Capital, Credit, Interest, and the Business Cycle. Cambridge, MA: Harvard University Press.

Stanziani, Alessandro, ed. 2005. La qualité des produits en France (XVIIIeXXe siècles). Paris: Belin.

Star, Susan Leigh, and James R. Griesemer. 1989. "Institutional Ecology, 'Translations' and Boundary Objects: Amateurs and Professionals in Berkeley's Museum of Vertebrate Zoology, 1907-39." Social Studies of Science 19 (3): 387-420.

Stark, David. 2009. The Sense of Dissonance: Accounts of Worth in Economic Life. Princeton, Princeton University Press.

- 2011. "What's Valuable?" Postscript to The Worth of Goods. Valuation and Pricing in the Economy, edited by Jens Beckert and Patrik Aspers, 217-36. Oxford: Oxford University Press.

Steiner, Philippe. 2012, La sociologie économique. Paris, La Découverte.

Trésor de la langue française informatisé (http://atilf.atilf.fr/).

Vatin, François. 1998. Economie politique et économie naturelle chez A.-A. Cournot. Paris: Puf.

—__ 2008a "L'esprit d'ingénieur: Pensée calculatoire et éthique économique." Revue française de socio-économie 1:131-52.

—. 2008b. "L'économie comme acte de gestion: Critique de la conception substantive de l'économie." Sciences de la société 73:165-84.

— mesure. Toulouse: Presses universitaires du Mirail.

Walras, Léon. 1984. Elements of Pure Economics: Or the Theory of Social Wealth. Philadelphia: Orion.

François Vatin, professor of sociology at Paris Ouest University, is the director of the Master Program "Economy and Society" and of the CNRS research center "Institutions et dynamiques historiques de l'économie" (IDHE) for Paris Ouest University. His research interests range from industrial sociology and economic sociology to the history of economic and social thought. Recent books include: Le travail et ses valeurs (Paris, Albin Michel, 2008), Traité de sociologie économique (edited with Philippe Steiner, Paris, PUF, 2009), Evaluer et valoriser: Une sociologie économique de la mesure (Toulouse, Presses universitaires du Mirail, 2009) and L'espérance-monde: Essai sur l'idée de progrès à l'heure de la mondialisation (Paris, Albin Michel, 2012). 